\title{
電気化学的分析の装置之実験法*
}

\section{安盛善 一**}

\section{1. 緒言}

戦後に打ける電気化学的分析の目覚しい進歩 は大戦中に打けるレーダーその他の電波兵器の 研究の為に得られたエレクトロニックスの知識 及び技術に負う所が大きい。

即ち分析の原理の考案は古くに行われていな がらその測定や制御方困難であつたり又は多く の学力を必要とした為, 分析法として普及しな かつた方法がエレクトロニツクスの新技術を導 入1することによつて再び注目される様になつ た。 さうしてをれらの方法は理論的にも再検討 され面目を一新する様な進歩がもたらされたと 考光られる。

一般に電気化学的分析は電極界面の現象を利 用するものと電解液の電導現象を利用するもの とに二大別するととができるが，乙とでは主と して前者に属するものについて述心゙ることとす る。電極界面の現象を利用する分析の進歩につ いては前述のエレクトロニツクスの貢献の他に ポーラログラフィーの発展によつて促進された ことを見逃すととができない，との詳細は最近 続々出版されたすぐれた成害によつてうかがう ことができるであろう。その主なものをあげる と舘 ${ }^{2)}$, 品川 ${ }^{3)}$, 不橋 - 藤永 ${ }^{4)}$, Lingane ${ }^{5)}$, Delahay ${ }^{6)}$, Willard et al. ${ }^{7)}$, Berl ${ }^{8)}$, Müller ${ }^{9)}$, Meites $^{10)}$, Kolthoff-Lingane ${ }^{(1)}$ 等の著暮がある.

而して此等の著書の出版はポーラログラフィ 一を中心とする電気化学的分析の研究が一応一 つの階段を登りつめたこと走示すのではないだ ろうか。卵ちこの 2,3 年前にこれらの研究は 理論的にも実験的にも一先づ確立され, 現在で は分析研究室汃らあら部門の化学研究室な

* Instrumentation and Methodology of Electroanalytical Chemistry

** Yoshikazu YASUMORI, (株)楖本犨作沂
り現場なりへの発展に進みつつあるものと考え られる ${ }^{12)}$

\section{2. ポーラログラフイー}

\section{a. 古典ポーラログラフイー}

古典ポーラログラフィーは依然ポーラログラ フィーによる分析に招いて最も重要な役割を果 し，ポーラログラフのペン記録化によつてその 応用は益々盛んとなりポーラログラフィーの倨 告は年間 600 以上と推測されている ${ }^{13)}$.

ポーラログラフのペン記録方式としては種々 の方式が考案されているが ${ }^{14)}$ ，我が国に扑いて 製品化されているのは何れもブリッヂ式補償回 路を用いた電子管式自動平衡方式である ${ }^{15)}$ 。ペ ン記録式ポーラログラフでは記録計の電流感度 の他にその動特性が問題となり ${ }^{16)}$ ，その制動回 路について理論的並びに実験的な検討が加えら れ17)，4重 Parallel-T RG 濾波回路によつて殆 んど振巾のないポーラログラムが得られた ${ }^{18)}$. 宋た電圧を正しく電極に加光る為の工夫も程々 行われている19,20).

ポーラログラフ 分析一般の問題としては精 度 ${ }^{21)}$ 及び感度 ${ }^{22}$ の向上を目指して破究刃゙続けら れた。即ち波高の测定 ${ }^{23,24)}$ ，吸着の諆差 ${ }^{25)}$ 等に ついても検討されたが，一方水銀㵜の最子成长 した時の瞬間電流は最も精度のよい（士0.3\%) ことが強調され26)，㝒た毛細管をシリコン樹脂 処理すれば滴下の再現性が向上されることが明 らかとなつた27)．感度の向上の為には四転水銀 電極 ${ }^{28)}$, 静止水銀電極 ${ }^{29}$, 流出水銀電極 ${ }^{30)}$, 回転 滴下水銀電極 ${ }^{31}$, 新型水銀電極 ${ }^{32}$ ) 等が考案され， 固体電㥛についても電極を廻転すると同時汇液 を攪挥して感度が向上せられた。间白金電極に つひては前処理の影響について精細な研究が行 われ ${ }^{33)}$ ，この研究の結果によつて電位差滴定に

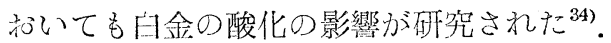

化学的字見地汃ら感度を向上する方法として 


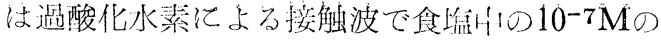
バナデンの起量が行われ， $\mathrm{Fe}^{+++}, \mathrm{Mo}^{+6}, \mathrm{~W}^{+6}$

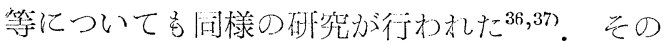
他注目す心゙き研究として EDTA 和よび類縁化 合物 ${ }^{38)}$ 或は才二ウム化合物 ${ }^{39)}$, 複合錯形成剂 ${ }^{[40)}$ 等の研究があり, 就中微量のテトラ・フエニー ル・アルソニウム・クロライドの添加によつて $\mathrm{Sn}^{+4}$ の波が荌定し ${ }^{4 \mathrm{I}}$ ，ポンタクロム・バイオレ ツト SW が $\mathrm{Al}$ の存在に打いて定量的に転移 し42)，EDTA の亜鉛塩は Ca イオンと定量的に 置換する ${ }^{43)}$ と等はこれらの分析精度を大いに 向上した。

有機化合物の分析に刘してはこの半波電位と 化学構尷の関連について電子論に從つて基礎的

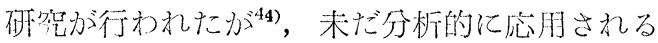
总でには至らず，妨害共存物質は他の物理化 学的方法による前処理で除くことが注目され た ${ }^{45)}$. 即ち例光ば $\gamma$-BHC の不純物はクロマト グラフ法で分離され ${ }^{46)}$ ，血液中の二トロ化合物 は抽出によつて精製されて77, ニトロ化合物の混 合物はカウンターカレント分配法によつて分離 して ${ }^{48,499}$ ポーラログラフにかけられた。

父化学的前処理法によつてポーラログラつ的 飞不活性子物質を活性化する研究も盛んとなり つつあり,ニトロソ化によつてアンチピりン ${ }^{50),}$ テラマイシン51)が，ラネーニッケル处理で有機 化合物の硫黄 ${ }^{22}$ 少定量され, Schöberl 法によつ

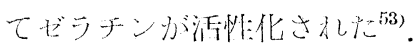

\section{b. 新しいポーラログラフイー}

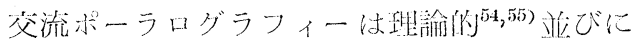

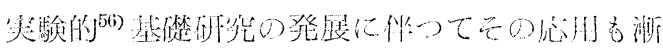
次発展し，父流ブリツヂ者心做した独創的なく ン記録装置も発明された衫?。交流ボーラログラ フィーで分析上贋々妨害となる ${ }^{587}$ 蓄電器電流の 除去について滴下间期装置芦用いたり ${ }^{59)}$ ，或は

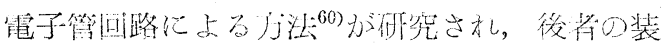

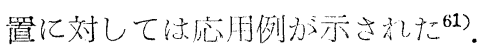

又交流ポーラログラフィーでは電気分解によ る波の他に電極党の吸着脱着によつて波のでる

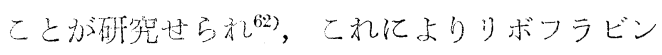
の異常波は非常に高い波が出るのでその分析的 灾用が期待されている
オツシログラフポーラログラフィーをしでは 電流規定のHeyrovsky-Forejt 型と電位規定の Randles-Sevcik 型とが平行して発展した ${ }^{64)}$. 前 者䄈 Electronic Polaroscope として市販され， その測定は武料溶液と参照溶液の $d V / d t=f(V)$ 曲線をチヨツパーによつて交互にブラウン管に 現わし，阿者が一致するまで参照溶淮の浱度を 高め，一致した時の参照溶液の莀度汃ら試料溶

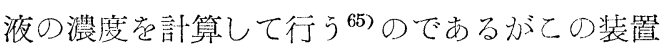
老用いて $d V / d t=f(V)$ 又は $d V / d t=f(t)$ 曲線 の谷の深さによつて分析する方法も考案され た66). 宗た単交流周期つ装置も考案されこれに よると $5 \times 10^{-6}$ の硫黄が検出される ${ }^{67)}$.

Randles-Sevcik 型のものもやはり市販される 様になり ${ }^{(6)}$ 前者と同し様にチヨッパーを用いる 装置も教案されだ：尚掃引を機械的に0.15〜 28秒の䧓期で与光る方法 ${ }^{70)}$ はオツシログラフポ ーラログラフの一つの方向を示すものであろ 5.

電流規定のポーラログラフィーは固体電極を 伐用した場合でも波が極大 (time maximum) 老示さない利点がある71)ので研究が始方られ， 鉄鉱中の鉄やフエニレンヂアミン 72)の分析に用 いられた。宗たこの方法は滴下水銀電極につい ても检討せられ年，一方定電流ボルトアンメト リー -74) はクロノポテンシオメトリー7市とも呼ば

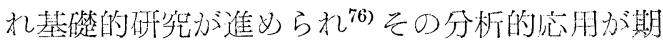
待世られてい\%77,78)。

\section{3. 電気分解法}

\section{a. 電解分離法}

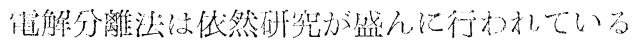

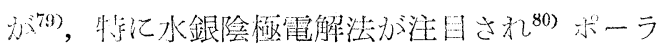
ログラフ法とも仵用せられている ${ }^{81)}$. 磁力で電 解液と水銀党逆方向に流動さ也ると電解時間か 非常に短縮されるので82,83)，この装置が我国に ても市販される様になり，磁気水銀陰極電解法

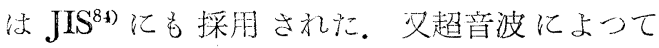
電解特閐老短縮する方法についても砸究さ扎 た

定電位電解法仗ポーラログラフィーの理論と 経験の導人及び機器による自動化によつて大い 


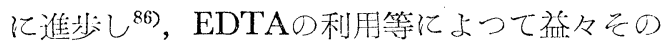

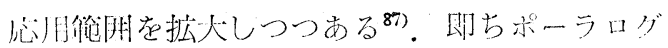
ラフ法の結果を基礎にしてビスマスからの銅の 分離隹成功し ${ }^{88)}$, 続いて銅属元素の逐次分離:迁 量法が砄究せられた89). 又アマルガムの溶出も 分析に利用されカドそウムアマルガム中の痕跡 の雨鉛を溶出させててれをポーラログラフ法に かけるととができ90)，定電位溶出定行え将西鉛 から鉄を分離するととも可能となつた ${ }^{91)}$.

\section{b. クーロメトリー}

電気化学の根本法則の一つである Faraday の法則はクーロメトリーとして分析化学化古く から忘网されているが，電量滴定の発展に伴つ てクーロメトリーの重要性が再誌識された。即 ち電量滴定法は標準試薬学作製する必要がな く, 試薬発生の電気量から物質量岂測定するて とができるから，天科の力をからない分析法と して特異性を持つているわけである ${ }^{93,94) . ~}$

電量滴定は電気化学的分析の中で現在最も活 潑飞研究の行われている分野の一つで, その研 究にはNernst 式による平衡電位の他にポー ラログラフィーに基づく運動論的解勫肪必要 で95)，殊汇電流規定のポーラログラフィーがそ の基礎条件の決定に有用であることぶ強調せら れだ71).

電量滴定に打ける電解は定電流電解によるこ とが多いが，との定電流電源としては多くの装 置が考案せられ，電子篔平衡式のもの ${ }^{96)}$ やラ

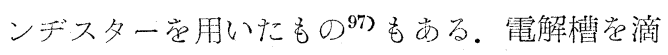
定槽と分離した外部発生電解槽の研究によつて 電量滴定の応用範用が広宗り ${ }^{98)}$. $1 \mathrm{~A}$ 以上の電 解電流を流せる two-arm cell ${ }^{999}$ や中和滴定をの 他に用いるととのできる single-arm cell ${ }^{100,101)}$ も考案された。電量滴定は八ロゲンで滴定する ものが多いが Karl Fischer 試薬を発生する斤

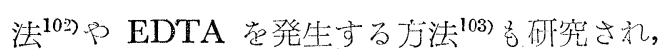
極微量滴定にも応用されだ ${ }^{104)}$.

一方電量滴定はその自動化が容易であるので よく研究せられ, 市販の自動電位滴定装置党用 いてもその自動化が可能であるととが明らかに された ${ }^{105,106)}$. 更に一定速度で流れている試料 に対して連続的に電量㵜定在実施する場合には

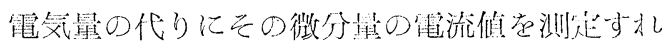
ば試料の滇度が解るわけである107)。てのう江沉

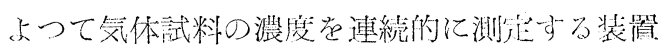

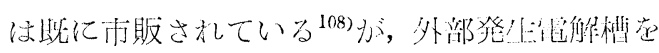
使用して液体試料を連続的飞電量湖定与るj江

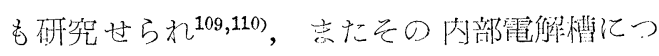

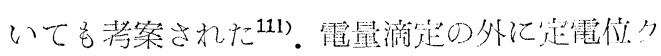
一ロメトリーもクーロメーターの発達に伴つて

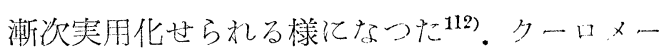
ターとしては種々の考案があるがサーボ機䅉老 利用した装置は広範四の電流にわたつて西确で ある11.3).

\section{4. アンペロメトリー及びポテン シオメトリー}

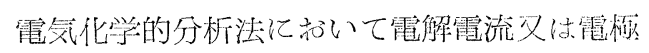
電位老測定するには従来ガルバノメーターがよ く用いられてきたが、エレクトロニツクスの発 洼に伴つて漸次真空管增巾器がその代りに用い られる様になり，交流变換増门方式の採用によ り増币器の信頼度も高まりとれらの測定の操作 も非常に容易になつだ ${ }^{114)}$.

又アンペロメトリーとポテンシオメトリーの 意義について從来充分な関係づけが行われてい なかつたが，ポーラログラフィーの発展によつ

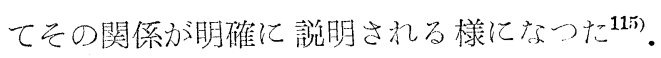

\section{a. アンペロメトリー}

ポーラログラフ法から発屡したアンベロメト リーはポーラログラフィーの連続分析への応用 として試みられ Corn Steep Liquor 中の画硫 酸116)や酸素の定量 ${ }^{117)}$ 等が連続分析された。宗 たとの場合滴下水銀電極を使用することについ

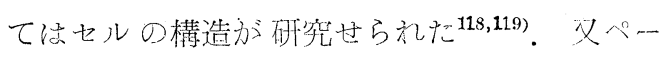
パークロマトグラムの検出法としでァンペロ メトリーが利用せられた120).

しかしアンペロメトリーが最もしばしば用い られるの海容量分析の終点判別法としてであつ てとの法は電流滴定法と名付けられ，イオン 結合反応，酸化還元反応，沈澱反応による滴定 に広く用いられ121)電量滴定にも利用されその 自動滴定装置も考案された狙). 尚ポーラログラ フィーとは别個に古くから行われていた Dead 
Stop 法も本質的には電流滴定に通ずるととが

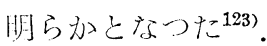

\section{b. ポテンシオメトリー}

ポテンシオメトリーを分析に利归して最も塑 及しているのは $\mathrm{pH}$ 測定で, $\mathrm{pH}$ の大部分の測定 が現在ではポテンシオメトリーによつて抲り殊 にガラス電檽学用いるう汇が普通行われてい る ${ }^{124)}$. 尚ポテンシオメトリーは $\mathrm{pH}$ の外飞微量 の酸素125)，塩素イオン ${ }^{126)}$ ，硫化水素127) 等にも 用いられた。しかしポテンシオメトリーもアン ペロメトリーと闰様に滴定の終点判別法として の応用が分析上最も重要で ${ }^{128)}$ ，アンペロメトリ 一に扔ける Dead-Stop 法に刘しポテンシオメ トリーでは Derivative Polarographic Titration 尼刘応させて考えるととがでさ123)，後者の方 が真空管増门器を用いるのに签易であるから Dead-Stop 法は漱次 Derivative Polarographic Titration に礼き加わりつある。不可逆系と 不可逆系の組合せの滴定に打ける終点判别法と

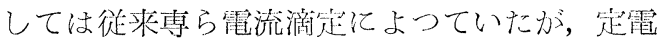
流分栖ポテンシオメトリーが再び注日されとの 方面に使用される様に尔つた。即ち EDTA に 上るカドるウム ${ }^{129)}$ ，鍴间 ${ }^{130)}$ の滴定等に用いられ た。卖た是電流分極ポテンシオメトリーに礼い て交流分極させる方法も研究され多くの実験例 が示された131).

ガラス電極 $\mathrm{pH}$ 計の発達に伴つて中和滴定に 扣ける電位滴定の利用は益々盛んとなり殊に非 水溶媒を用いることにより中利湳定の終点が鋭 くなること分明らかとなりとの广面の研究も多 い142). 一方自動滴定装置の研究も電位滴定に関 するものが最も多く，終点電位に達するまで激 下させる装置の外に㵜定中の電位変化の二次微 分が零になるまで湳下させる装置 ${ }^{133,134)}$ や流体 陚料を連続して 㵜定する連続自動滴定装置 ${ }^{135)}$ も研究せられた。

\section{5. コンダクトメトリーと電気泳動法}

\section{a. ヨンダタトメトリー}

電気任導法に上る分析はこの測定装置が比較 的簡㧛であるので管理用分析法として多く用い られ，硝酸一過陵化䇪素一水素の分析 ${ }^{136)}$ ，ガス

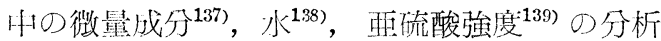
飞成用された。コンダクトメトリーもアン・ロ メトリーやポテンシオメトリーと闰様に滴定の 終点判别法としても㐫用され EDTA による擜 定 ${ }^{100)}$ 等任利用され，来たこの場合の滴定甠線か ら終点を求邓る开確な方江汇ついて砸究され $た^{141)}$.

宮周波分析についてはコンデンサー型142,143) 及びコイル型144 145)について大々理論的に究明

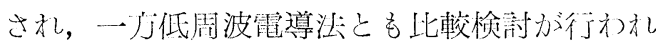

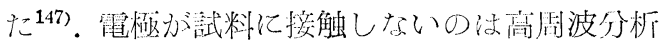

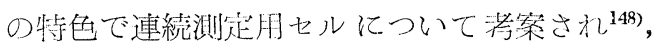

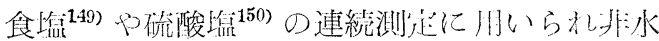
溶媒の滴定も行われた ${ }^{151)}$.

\section{b. 電気泳動法}

電気泳動による分離法は主として生物兴的な 䃊究に利用せられているが特に電㸚クロマトグ ラフ汇の発展が目覚吾しい ${ }^{152)}$. 電父クロマトグ ラフ法の媒体としては稀薄寒天，メチルセロソ ルブ, 㦛天ゲルの様な粘度の高い溶液, 澱粉, ガラ久粉，セルローズ，イオン交換樹脂の様な 粉体及び糸や紙の様な繊維物質が用いられ就中 濾紙電父(泳動法业最も多く用いられた153).

滤紙の保持法としては水平に伸張する方法 ${ }^{154)}$ とガラス棒にかける方法墳々゙があり，非電導性

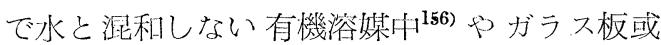
は合成樹脂板の間に打き垆7)，或はポリエチレン シートで被つたり冷却槽の上に置いたりするこ とも研究されだ洦)。

無機物に対する電気クロマトグラフ法につい ては時間，電位傾度，温度，試料濃度，試料附 着量等の影響との他の基磼的研究 ${ }^{159}$ 並びに硅 々の錯イオンについて䃑究が進少られた ${ }^{160)}$ 。 た試料学連続的に添加する連続電気クロマトグ ラフ法は分離された物質を夫々単離精製するの に便利なので蛋白質や放射性物質の精製に濑次 心用される様になつた

\section{6. 結}

言

電気化筞的分析の分野は韭常に広汎にわたり 菲力の著者が到底をの全貌を述べるのは不可能 であるので，以上述べた所も概括と云うよりも 


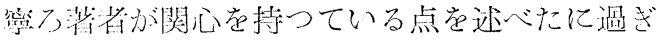

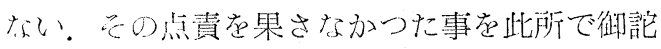
びして执きたい。

\section{收近の分析化学の問題として工程管理の分析} が白動制動その他に関連して重要視されている が, 電気化学的分析法はこの方面えの発展が期 待されるので流ないであ万うか。就中自動制御 の為の分析法として電気化学的分析は最も適当 なものと考光られる。乙の意味飞拝いて著者は 電気化学的分析の今後の目覚しい進歩赏期待し て烻わ机いのである。

\section{交献}

1）立花，古賀編：化学者のためのエレクトロニック ス, 南江堂 (1956).

2) 舘編：ポーラログラフィー，岩波 (1954).

3）品川: ポーラログラフ分析法, 共立 (昭27).

4) 石橋, 藤永: ポーラログラフ分析法, 丸善(昭 30 ).

5) J. J. Lingane : "Electroanalytical Chemistry", Interscience, N.Y. (1953).

6) P. Delahay: "New Instrumental Methods in Electrochemistry", Interscience, N.Y. (1954).

7) H.H. Willard, L. L. Merritt, Jr., J. A. Dean : "Instrumental Methods of Analysis", 2nd Ed. D. Van Nostrand Co., Inc., N. Y. (1948). (日 本語訳, 日本分析化学会編：機器による化学分析, 丸善 (昭29)).

8) W. G. Berl: "Physical Methods in Chemical Analysis", Academic Press, N.Y. (1951).

9) O.H. Müller: "Polarographic Method of Analysis", J. Chem. Education, Easton, Pa.(1951).

10) L. Meites: "Polarographic Techniques", Interscience, N.Y. (1955).

11) I. M. Kolthoff, J.J. Lingane: "Polarography", 2nd Ed., Interscience, N.Y. (1952).

12) 日本分析化学会近畿支部編：機器分析実験書，楅 書店 (昭31).

13) D.N. Hume: Anal. Chem., 28, 625 (1956).

14) 仁木: 化学の領域, 10, 203 (1956).

15) 仁木：ポーラログラフィーの研究， 1， No. 4, P. 27 (1954).

16) 安盛: ポーラログラフィー， 3，26 (1955).

17) 仁木：ポーラログラフィー，3，75 (1955).

18) M. T. Kelley, D. J. Fischer: Anal. Chem., 28, $1130(1950)$.
19) W. Jackson, P.J. Elving: Anal. Chem., 28, 378 (1956).

20) R. L. Pecsok, R. W. Farmer: Anal Chem., 28, 985 (1956).

21) 中川：ポーラログラフィーの砄究， 1， No. 1， 42 (1953)

22) 藤永：ポーラログラフィー, 3, 101 (1956).

23) Y. Yasumori : Bull. Chem. Soc. Japan, 27, 554 (1954).

24）錫谷：ポーラログラフィー， 2，70 (1955).

25）錫谷: ポーラログラフィー, 2, 169 (1955).

26) H.A. Dell, G.H.R. Gentry: Phillips Гech. Rev., 14, 257 (1953).

27) M. Stackelberg, V. von Toome : Leybold Pol. Ber., 1, 55 (1953).

28) T.S. Lee: J. Am. Ghem. Soc., 74, 5001 (1952).

29) G. A. Streuli, W. D. Cooke: Anal. Chem., 25, 1691 (1953).

30) P. Lévêque: J. Chim. phys., 49, 269 (1952).

31) W. Stricks, I.M. Kolthoff : J. Am. Chem. Soc., 78, 2085 (1956).

32) Y. Yashiro: Bull. Chem. Soc. Japan., 27, 564 (1954).

33) I. M. Kolthoff, N. Tanaka: Anal. Chem., 26, 632 (1954).

34) J. W. Ross, I. Shain : Anal. Chem., 28, 548 (1956).

35) 武藤，岡：ポーラログラフィーの研究， 2， 195 (1955).

36) I.M. Kolthoff, E.P. Parry: J. Am. Chem. Soc., 73, 3718 (1951).

37) G.P. Haight: Anal. Chem., 23, 1505 (1951).

38) 守永：ポーラログラフィー，4，19 (1956).

39) 品川, 松尾: 分析化学, 4, 211 (1955).

40) 石橋, 藤永, 佐藤：日化誌，77，696 (1956).

41) I. M. Kolthoff, K. A. Johnson: Anal. Chem., 23, 574 (1951).

42) H. H. Willard, J. A. Dean : Anal. Chem., 27, 1913 (1950).

43) R. Pribil, Z. Roubal : Collection, 19, 252(1954).

44) 小出: 電気化学, 23，484 (昭30).

45) 松本: 莧学研究, 27, 171 (昭30).

46) J. Rosin, G. B. Rodan: Anal. Chem., 25, 817 (1953).

47) 福江, 梅津, 笲盛, 石川, 中村: 学㗢科学, 29, 169 (1953). 
48) F.G. Angell : Analyst, 78, 603 (1953).

49) W. Kemula, D. Sybilska, J. Geisler : Roczniki Chem., 29, 838 (1955).

50) 松本：11本装学全件金管表 (1954).

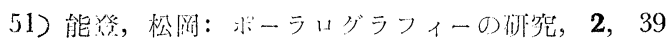
(1954).

52) A. Trifonow, T. Ivanow, D. Pawlow: Collection, 19, 1133 (1954).

53）秦，松下：日本器哣化学全大会桨表 (1954).

54) I. Tachi, T. Kambara: Bull. Chem. Soc. Japan, 28, 25 (1955).

55) B. Breyer, S. Hacobian: Australian J. Chem., 7, 225 (1954).

56) M. Senda, M. Okuda, I. Tachi : Bull. Chem. Soc. Japan, 28, 31 (1955).

57) 仁木: 電氛化学, 22, 433 (昭29).

58) P. Delahay, T. Adams: J. Am. Chem. Soc., 74, 5740 (1952).

59) 安盛: 䨘父化学，24，309 (昭31).

60) G. C. Barker, I. L. Jenkins : Analyst, 77, 685 (1952).

61) D.J. Ferrett, G.W.C. Milner: Analyst, 81, $19_{3}$ (1956).

62) B. Breyer, H. H. Bauer: Australian J. Chem., 8, 480 (1955).

63) 竹盛，舘：将ーラログラフ討論会 (1955).

64) J. Forejt (千四訳)：ポーラログラフィー，3，9 (1955).

65) R. Kalvoda, J. Macku : Collection, 20, 254 (1955).

66) R. Kalvoda: Collection, 20, 1503 (1955).

67) R. Kalvoda, J. Macku, 21, 493 (1956).

68) Sindak: Anal. Chem., 28, No. 7, 44 A (1956).

69) P. Valenta, J. Vogel : Collection, 21, 502(1956).

70) I. Shain, A. L. Crittenden: Anal. Chem., 26, 281 (1954).

71) R. N. Adams, G. N. Reilley, N. H. Furman : Anal. Chem., 25, 1160 (1953).

72) R. E. Parker, R. N. Adams : Anal. Chem., 2', 828 (1956).

73) 不橋, 藤永: 電気化学, 24, 375 (1956).

74) P. Delahay, G. Mamatov : Anal. Chem., 27, 478 (1955).

75) G.N. Reilley, G.W. Everett, R.H. Johns : Anal. Chem., 27, 483 (1955).

76) M.M. Nicholson, J.H. Karchmer: Anal. Ghem.,
27, 1095 (1955).

77) П111: 化学の领域, 9, 638 (1955).

78) 塚本: ポーラロダラフィー，4，3 (1956).

79) D.D. DeFord: Anal. Chem., 28, 660 (1956).

80) J. A. Maxvoell, R. P. Graham: Chem. Revs., 46, 471 (1950).

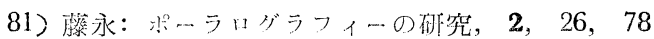
(1954).

82) E. J. Center, R. C. Overbeck, D. L. Chase: Anal. Chem., 23, 1135 (1951).

83) 神森: 分析化学, 2, 226 (1953).

84) JIS G 1227, JIS G 1230.

85) 中野, 高术: 雪父化学, 22, 472 (1954).

86) 藤永, 武藤：分析化学，4，321 (1955).

87) 是川, 石橋, 藤永: 分析化学, 4, 610 (1955).

88) J. J. Lingane, S. L. Jones: Anal. Chem., 23, 1798 (1951).

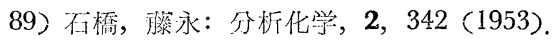

90) G. Scacciati, A. D'Este: Chimie e industria (Milan) 37, 270 (1955).

91) H. Coriou, J. Huré, N. Meunin: Anal. Chim. Acta, 9, 171 (1953).

92) 桃木：分析化学, 4, 646 (1955).

93) 奌橋: 化学の領域, 9, 463 (1955).

94) 徒木: 電気化学, 22, 431 (1954).

95) R. Gauguin, G. Charlot: Anal. Chim. Acta, 7, 408 (1952).

96) J.J. Lingane: Anal. Ghem., 26, 1021 (1954).

97) N. H. Furman, L. J. Sayegh, R. N. Adams : Anal. Chem., 27, 1423 (1955).

98) D. D. De Ford, J. N. Pitts, G. J. Jones: Anal. Chem., 23, 938 (1951).

99) N. Bett, W. Nock, G. Morris : Analyst, 79, 607 (1954).

100) J.N. Pitts, D.D. DeFord, T.W. Martin, E.A. Schmall : Anal. Chem., 26, 628 (1954).

101) W. Fuchs, W. Quadt: Z. anal. Chem., 147, 184 (1955).

102) A.S. Meyer, C.M. Boyd: U.S. Atomic Energy Commission, Rept. ORNL-1899 (May 20, 1955).

103) G.N. Reilley, W.W. Porterfield: Anal. Chem., 28, 443 (1956).

104) R. Schreiber, W.D. Cooke: Anal. Ghem., 27, 1475 (1955).

105) G.E. Gerhardt, H.C. Lawrence, J.S. Parsons ; 
Anal. Chem., 27, 1752 (1955).

106) J.S. Parsons, W. Seaman, R.M. Amick: Anal. Chem., 27, 1754 (1955).

107) 仁术：化学と工業，9，113 (1956).

108) C.E.C.: 電気化学, 22, 249 (1954).

109）山下，高橋，山本：計測， 5, 190 (1955).

110) 高橋, 术: 生産研究, 7, 50 (1955).

111)シーメンス，ウント，八ルスケ，ァクエンゲゼ ルシヤフト：特許出願公告，昭31〜 5198.

112) J. J. Lingane, J. A. Page: Anal. Chim. Acta, 13, 281 (1955).

113) L. Meites: Anal, Chem., 27, 1116 (1955).

114) R.H. Müller: Anal. Chem., 28, 649 (1956).

115) 石橋，藤永：電気化学，23， 494 (1955).

116) L. D. Wilson, R. J. Smith : Anal. Chem., 25, 334 (1953).

117) F.E. Armstrong, R.J. Heemstra, G.W. Kincheloe: Anal. Chem., 27, 1296 (1955).

118) L. D. Wilson, R. J. Smith : Anal. Chem., 25, 218 (1953).

119) W.H. Jura: Anal. Chem., 26, 1121 (1954).

120) A. Langer: Anal. Chem., 28, 426 (1956).

121) H.A. Laitinen : Anal. Chem., 28, 666 (1956).

122) H.L. Richter: Anal. Chem., 27, 1526 (1955).

123) I.M. Kolthoff: Anal. Chem., 26, 1685 (1954).

124) R. G. Bates: "Electrometric pH Determination", Wiley, New York, 1954.

125) T. B. Lancher, M. Czuha: Anal. Chem., 26, 1351 (1954).

126) M. Chanin: Science, 119, 323 (1954).

127) F. Cuta, Z. Burianac: Chem. Listy, 49, 503 (1955).

128) G. N. Reilley: Anal. Chem., 28, 671 (1956).

129) R.N. Adams: Anal. Chem., 26, 1933 (1954).

130) 田中: 分析化学，4，640 (1955).

131) U.F. Franck: Z. Elektrochem., 58, 348(1954).

132) J.A. Riddick: Anal. Chem., 28, 679 (1956).

133) 高术，前川：分析化学，3，484 (1954).

134) H.V. Malmstadt, E.R. Fett : Anal. Chem., 26, 1348 (1954).

135) 牧島, 米田, 森川, 宮尾: 工化誌，59，878(1956).

136) D.M. Mason : Anal. Chem., 27, 1135 (1955).

137) 高橋: 化学の領域, 7, 783 (1953).

138) G. Knowles, R. Briggs, L. J. Scragg : Chemis- try \& Industry, 1951, 700.

139) E. F. Thode, H. Freeman : Paper Trade J., 138, 14 (1954).

140) J.L. Hall: Anal. Chem., 26, 1484 (1954).

141) E. Grunwald : Anal. Chem., 28, 1112 (1956).

142) C.N. Reilley, W.H. McCurdy: Anal. Chem., 25, 86 (1953).

143) R. Huber, K. Cruse : Z. Elektrochem., 58, 156 (1954).

144) J.R. Haskinr, G. Heller, E. Miller : J. Chem. Phys., 23, 755 (1955).

145) 大庭，一条，高木：日化第 7 作会 (1954).

146）中楚：日化第 7 年会 (1954).

47) J. L. Hall, J. A. Gibson, H. O. Phillips, F. E. Critchfield: Anal. Chem., 26, 1539 (1954).

48) 武者, 武田：分析化学，5，459 (1956).

1 49) 武者, 矢野, 武田, 和田: 工化誌，58，482(1955). 150) 武者, 武田, 和田, 井上：工化誌，58，486(1955).

151) M. Ishıdate, M. Masui : Pharm. Bull, 2, 50 (1954).

152) H.H. Strain, T.R. Sato: Anal. Chem., 28, 687 (1956).

153）森, 小林：滤紙電気泳動法の実際，南江堂， 1955.

154) H.J. Mc Donald, R.J. Lappe, E.P. Marbach, R. H. Spitzer, M.C. Urbin: "Ionograph. Electrophoresis in Stabilized Media", Year Book Publishers, Chicago, Ill., 1955.

155) A. R. Ghosh : Naturwissenschaften, 41, 257 (1954).

156) F. Scheffer, W. Ziechmann, H.-D. Becker, H. Schüter: Naturwissenschaffen, 42, 71 (1955).

157) J L. Engelke, H.H. Strain : Anal. Chem., 26, 1872 (1954).

158) T. R. Sato, W. R. Norris, H.H. Strain: Anal. Chem., 27, 521 (1955).

159) 牧：分析化学， 3, 311，314 (1954), 4, 74, 156 (1955), 5, 23 (1956).

160) 牧: 分析化学, 3, 393 (1954)，4，21，217，302, $377,413,512,547$ (1955), 5, 138 (1956).

161) R.J. Block, E.L. Durrum, G. Zweig: "Manual of Paper Chromatography and Paper Electrophoresis", Academic Press, New York, 1955.

(1956-9-27受理!) 